\title{
THE DYNAMICS OF THE RUPIAH EXCHANGE RATE IN 2017-2020
}

\author{
Muhammad Arief Aldila Susanto ${ }^{1)}$, Rr. Retno Sugiharti2)* \\ 1,2 Department of Economics Development, Faculty of Economics, Universitas Tidar, \\ Indonesia
}

\begin{abstract}
The exchange rate is one of the most important indicators in the economy. Moreover, with the increasing intensity of trade between countries, commonly referred to as international trade, this economic indicator becomes important for every country, including Indonesia. The change in the Indonesian exchange rate system to a freefloating system has made the exchange rate fluctuations more dynamic. The fluctuations are influenced by various factors, both internal and external. This study aims to determine the effect of the money supply $\left(M_{2}\right)$, foreign exchange reserves, SBI interest rates and world crude oil prices on the rupiah/dollar exchange rate in 2017-2020 both in the short run and in the long run. The data used is monthly time series data from 2017-2020. The analytical method used in this study is the Error Correction Model (ECM). The results in this study indicate that in the short run and long run the money supply and foreign exchange reserves variables have a significant effect on the rupiah exchange rate in 2017-2020.
\end{abstract}

Keywords: Money Supply, Foreign Exchange Reserve, SBI Interest Rate, World Crude Oil Prices, Exchange Rate

\section{INTRODUCTION}

The rapid flow of globalization and technological advances has made the flow of information between regions increasingly swift without being constrained by distance and regional boundaries. Globalization makes the international trade easier and more intensive. In practice, the international trade requires an acceptable and mutually agreed currency unit that will become the standard reference for the value of money.

The American dollar is a currency that has been widely used in international trade transactions. However, for Indonesia, the use of US dollar in its international trade transactions will cause the exchange rate of the rupiah against the US dollar to continue to fluctuate. According to Muzaky (2015) this can lead to the risk of changes in currency exchange rates that arise due to the uncertainty of the exchange rate itself. Nevertheless, the fluctuations in the exchange rate can be considered reasonable because since August 1997 Indonesia has begun to adopt free floating system (Yuliyanti, 2014). In such system, the position of the rupiah exchange rate against foreign currencies is determined by the market mechanism.

*Corresponding author. Email address: retno.sugiharti@untidar.ac.id 


\section{AFEBI Economic and Finance Review (AEFR)}

\section{Volume 5, No 02 (2020)}

Figure 1. Overview of the rupiah exchange rate against the us dollar year 20172020. Source: (kemendag, 2021a) (processed data).

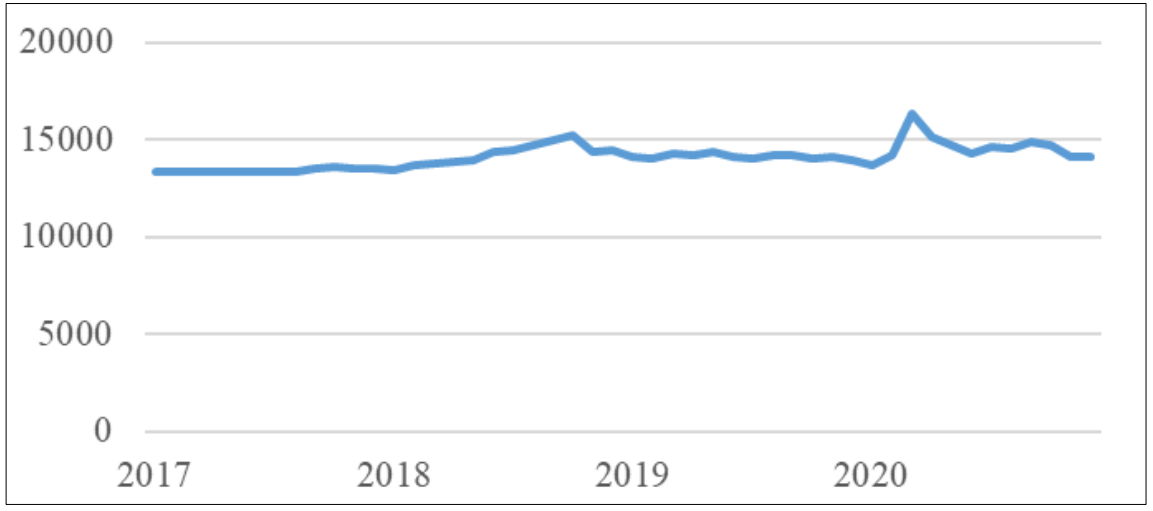

Figure 1 show that in the 2017-2020 period, the rupiah exchange rate fluctuated against the dollar. In addition, the rupiah exchange rate against the US dollar also tends to weaken or depreciate over the past four years. In January 2017, the rupiah exchange rate was at $\mathrm{Rp} 13,343 /$ dollar. The exchange rate has continued to depreciate for the last 4 years until in December 2020 which was at $\mathrm{Rp} \mathrm{14,105/dollar.} \mathrm{The}$ depreciation of the rupiah against the US dollar was triggered by the strengthening of the dollar against all world currencies.

The weakening of the Rupiah exchange rate against the US dollar is influenced by various factors, one of which is the money supply. Demak, Kumaat, \& Mandeij (2018) stated that the money supply can be defined in two ways, namely currency (M1) held by the public, and quasi-money and securities (M2) issued by the monetary system and owned by the domestic private sector with a remaining term of up to one year. The money supply plays an important role in the economy. In term of money, Triyono (2008) stated that an increase in the supply of money or the amount of money in circulation will increase the price of goods while at the same time also increasing the price of foreign exchange as measured in domestic currency. According to (Demak et al., 2018) (Yuliyanti, 2014) in the short and long run, the money supply had a positive effect on the exchange rate. This is in line with the research of Triyono (2008) which had proved that in the short run analysis the money supply has a positive impact on the exchange rate, but it has a negative effect on the exchange rate in the long run. 
Figure 2. Overview of the Indonesian Money Supply Year 2017-2020. Source: (Kemendag, 2021b) (processed data)

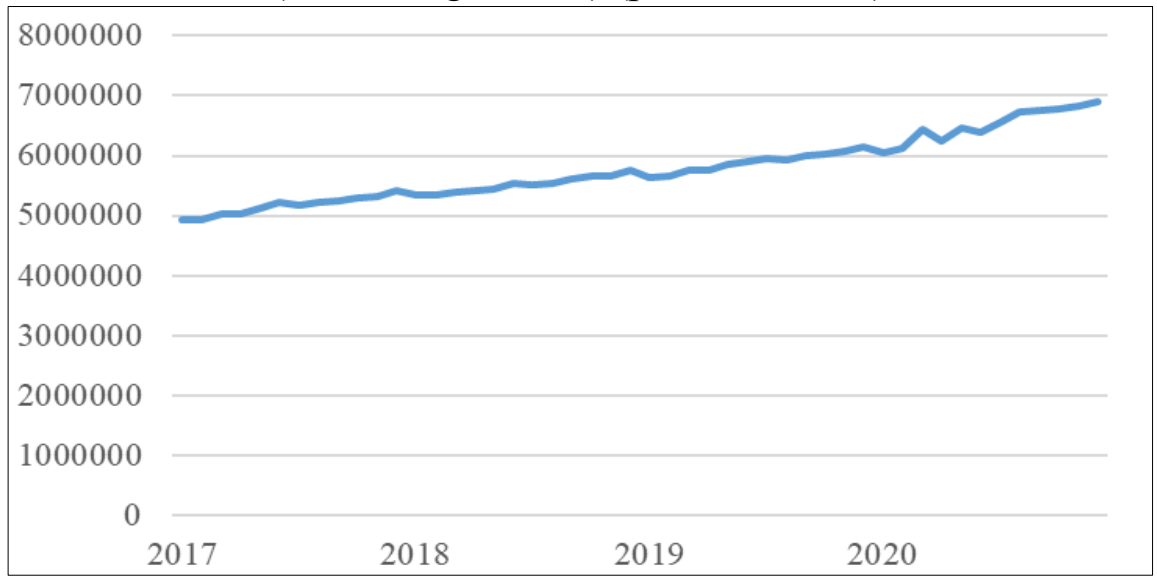

Another factor that is considered to influence the exchange rate of a country's currency is foreign exchange reserves. According to Emmanuel (2013) foreign exchange reserves are in the form of foreign currency, time deposits and foreign bonds held by the Central Bank and Monetary Authority of a country. Meanwhile Hady (2006) found that high foreign exchange reserves in a country indicate that the country has a great ability to conduct international economic and financial transactions. Research conducted by Yuliyanti (2014) found that in the short run, foreign exchange reserves had a negative and significant effect on the exchange rate, while in the long run it had a positive and significant effect.

Figure 3. Indonesia's Foreign Exchange Reserves (million US dollar) Year 2017-2020. Source: (BI, 2021b) (processed data)

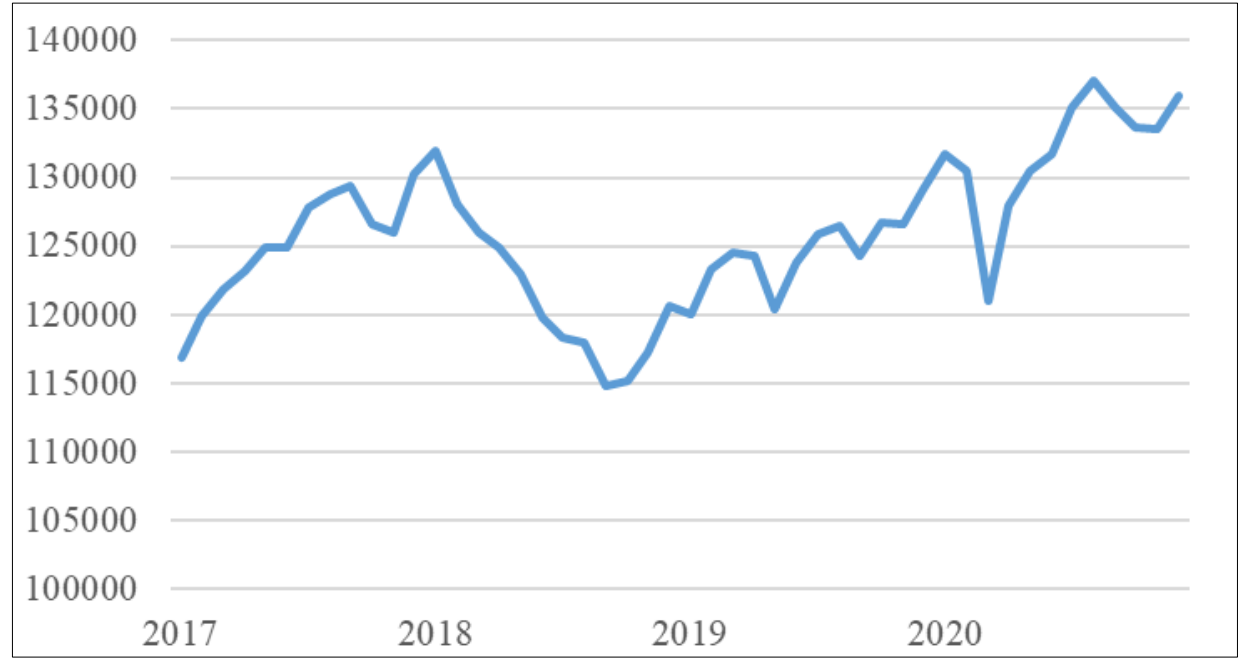

The next factor that is assumed to influence the exchange rate of a country's currency is the interest rate. Mishkin (2014) stated that the interest rate is the cost of borrowing or the price paid for the borrowed fund. In addition, the higher interest rate the more increase the demand for currency (Mirchandani, 2013), and the lower interest rate tends to reduce the exchange rate. The Bank Indonesia Interest Rate (SBI) is one of the mechanisms used by Central Bank to control the stability of the rupiah. Changes in interest rates will affect changes in the amount of demand and supply in the domestic money market. According to (Muchlas, Z., \& Agus, 2015) if 


\section{Volume 5, No 02 (2020)}

a country adheres to a free foreign exchange regime, then it also allows an increase in capital inflows from abroad. This will result in changes in the exchange rate of the country's currency against foreign currencies in the foreign exchange market.

Figure 4. SBI Indonesia Year 2017-2020 (in percentage). Source: (BI, 2021a)

(processed data)

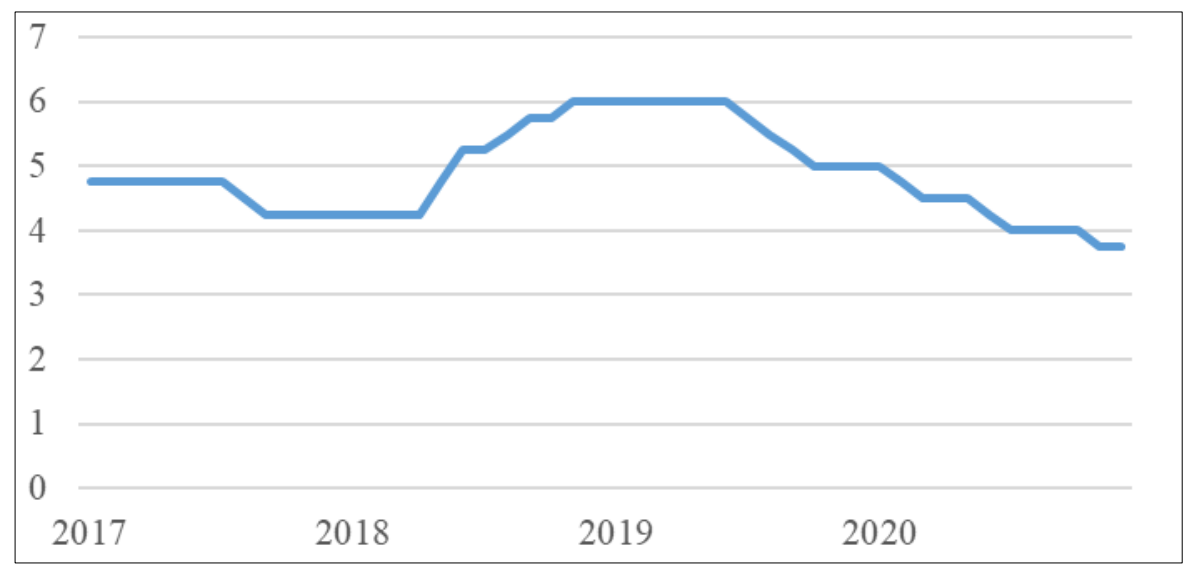

The figure above shows the amount of Indonesia's SBI for the last four years. During this time span, SBI has experienced fluctuations, where in January 2017 SBI was in the range of 4.75\%; in August 2017 SBI fell to 4.5\%. In September 2017, the SBI fell back to $4.25 \%$. This figure continued to hold until April 2018. It continued to experience an upward trend in May 2018 until June 2019, with the highest figure of $6 \%$. In July 2019, SBI began to experience a downward trend, where the trend occurred until December 2020 with the lowest figure of $3.75 \%$. The government's efforts to lower interest rates showed that the government wanted people to use bank loans to develop their business activities. Hazizah, N., Viphindrartin, S., \& Zainuri (2017) stated that with low interest rates, it was expected to spur people to use their funds in economic activities, rather than just saving them in the form of deposits. Research conducted by Yuliyanti (2014) had the result that in the short and long run the SBI rate had a negative and significant effect on the exchange rate. Meanwhile Triyono (2008) conducted research on the analysis of changes in the rupiah exchange rate against the dollar, and found that in the short run the SBI variable had a positive and insignificant effect on the exchange rate. While in the long run, the SBI variable had a positive and significant effect.

The last factor that is thought to affect the exchange rate is the world crude oil prices. World crude oil prices are measured from the spot price of the world oil market, generally West Texas Intermediate (WTI) or Brent (Artha et al., 2014) that are used as the standard. Crude oil traded on WTI is high quality crude oil. The crude oil is light-weight and has low sulfur content. This type of oil is very suitable for use as fuel. This causes the price of oil to be used as a benchmark for oil trade in the world. Indonesia as one of the world's largest oil -importing countries is still very dependent on oil to drive the economy. The increase in world oil prices, in theory, will cause Indonesia to buy the oil at a higher price. This causes payments in dollar to increase that lead the demand for dollar increases and next will cause the rupiah to depreciate. Findings form research conducted by Pardede, A.S.M. \& Setiawina, (2018); Wijaya, (2020) that world oil prices had a negative effect on the rupiah exchange rate. 
Figure 5. World Oil Prices (US\$) Year 2017-2020 (percentage). Source: (Index Mundi, 2021) (processes data)

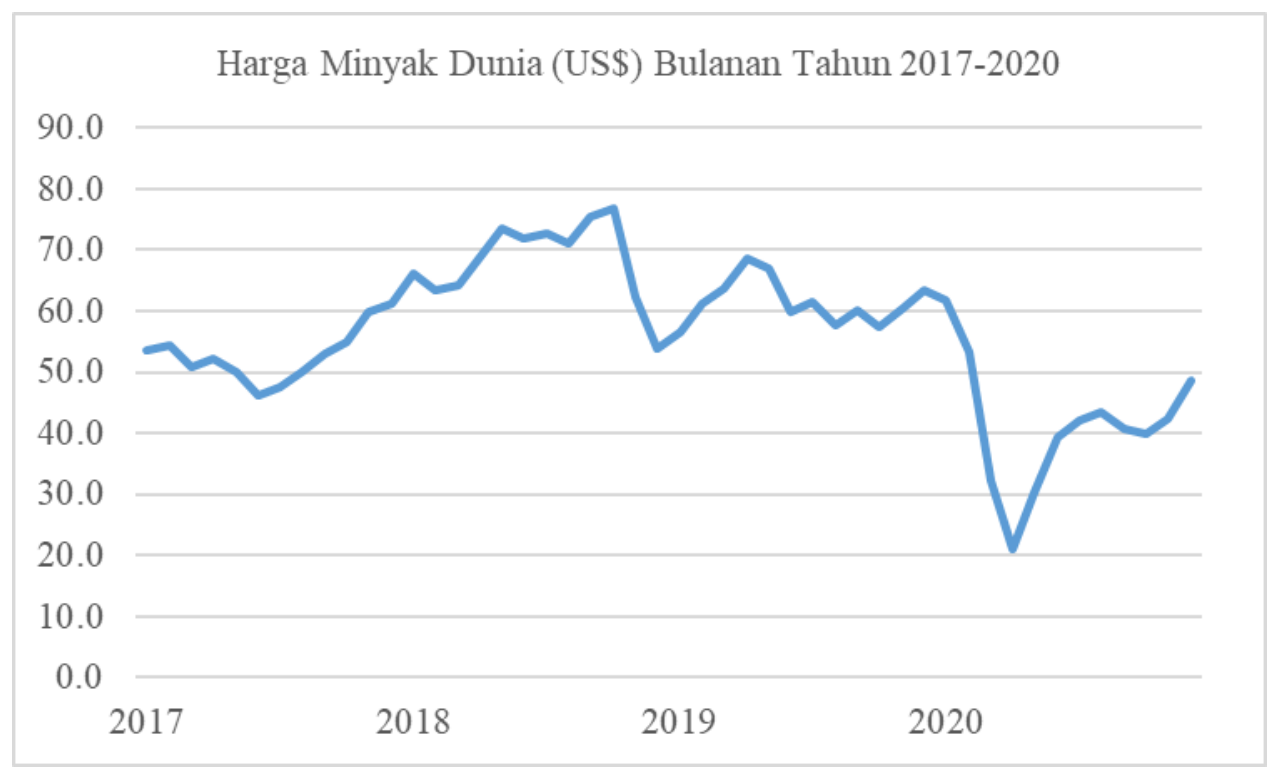

Previous studies related to the rupiah exchange rate, among others, is the study of Demak et al. (2018) which had the result that in the long run deposits rates, money supply, and inflation had a positive and significant effect on the exchange rate. In the short run, deposit rates had a positive and significant effect on the exchange rate, while the money supply and inflation had a positive but not significant effect on the exchange rate.

Research conducted by Triyono (2008) using the Error Correction Model (ECM) analysis method, had the result that in the short term inflation, SBI and imports variables had no significant effect on the exchange rate at $\alpha=5 \%$. Meanwhile, the amount of money in circulation had a significant effect on the exchange rate at $\alpha=$ $5 \%$. In the long-term regression variables of inflation, the money supply, SBI, and imports had a significant effect on the exchange rate at $\alpha=5 \%$.

Then research of Yuliyanti (2014) which also had use the Error Correction Model (ECM) showed the result that in the short run the variables that affect the exchange rate were foreign exchange reserves and SBI interest rates. Meanwhile, in the long run, all variables, namely the money supply, SBI interest rate, imports and foreign exchange reserves had a significant effect on the rupiah/US dollar exchange rate in 2001-2013. Then research by Pardede, A.S.M. \& Setiawina (2018) showed that based on the results of simultaneous testing, the composite stock price index, interest rates and world oil price had a significant effect on the rupiah exchange rate for the period 2012-2016. Partially, the composite stock price index and interest rates had a significant and positive effect on the rupiah exchange rate in 2012-2016. Meanwhile, the variable world crude oil prices partially negatively and significantly affected the rupiah exchange rate in 2012-2016. Next, research by Wijaya (2020) which had the result that in the short run, the interest rates and world oil prices had a significant effect on exchange rates. World oil prices had a significant negative effect on exchange rates both in the short run and in the long run.

The importance role of the exchange rate in supporting the economy of a country made it interesting to discuss and see changes or fluctuations that are influenced by various factors. Based on the description above, it is important to conduct an in-depth study of the dynamics of the rupiah exchange rate. The purpose of this study was to 


\section{Volume 5, No 02 (2020)}

determine the effect of the money supply, foreign exchange reserves, SBI interest rates and world crude oil prices on the rupiah exchange rate in 2017-2020 in the short and long run.

\section{LITERATURE REVIEW}

\section{The influence of the Money Supply on the Rupiah Exchange Rate}

In Demak et al. (2018), the excess money supply in a country's economy put pressure on the exchange rate of the country's currency against foreign currencies. Triyono (2008) highlighted an increase in the supply of money or the amount of money in circulation increased the price of goods as measured by the terms of money and would also increase the price of foreign exchange as measured by the domestic currency. Then the first hypothesis in this study was:

H1: The money supply has a positive influence on the exchange rate in the 20172020 period, both in the short and long run.

\section{The Effect of the Foreign Exchange Reserves on Exchange Rates}

The more foreign exchange or foreign exchange owned by the government and residents of a country, the greater the ability of that country to conduct international economic and financial transactions and the stronger the value of that country's currency. Then the second hypothesis in this study was:

H2: Foreign Exchange Reserves have a negative effect on Exchange Rates in the 2017-2020 period, both in the short and long run.

\section{The Effect of Interest Rates on Exchange Rates}

Interest Rates greatly affect the exchange rate of a currency against another currency. The higher the interest rate of a currency, the higher the demand for that country's currency. According to (Mishkin, 2014) a decrease in domestic interest rates caused a depreciation or weakening of the domestic currency exchange rate and an increase in domestic interest rates caused an appreciation or strengthening of the domestic currency exchange rate. Then the third hypothesis in this study was: H3: SBI have a negative effect on the exchange rate in the 2017-2020 period, both in the short and long run.

\section{The Effect of World Oil Prices on Exchange Rates}

Mulyani (2015) stated that world oil prices have a relationship with the exchange rate. In the short run, an increase in oil prices caused an increase in the price level which leads to a decrease in demand and output. According to Pardede, A.S.M. \& Setiawina (2018) in the medium term, the increase in oil prices caused a decrease in the real wages paid by companies, thereby increasing natural unemployment and further lowering the natural level of output. A rise in world prices would also cause an increase in the price of domestic goods because most domestic companies still use oil as a raw material for production. This increase in the price of domestic exchange rate against the US dollar to depreciate. So, the fourth hypothesis in this study was: H4: World oil prices have a negative influence on exchange rates in the 2017-2020 period, both in the short and long run.

\section{RESEARCH METHOD}

The method used in this research was the Error Correction Model (ECM) Analysis. This regression analysis aims to determine the short run and log run effects 
of the independent variables on the dependent variable and help to overcome nonstationary data and avoid spurious regressions. In analyzing the data using ECM method, there are several tests, namely Stationarity Test, Cointegration Test, Error Correction Model and Classical Assumption Test. Data processing was carried out using the E-views version 10 software.

For this study, the data used was monthly time series data using data on the Rupiah/US dollar exchange rate, the money supply (M2), foreign exchange reserves and SBI interest rates and also oil prices/world oil prices for 2017-2019. This type of data is secondary data obtained from several sources, namely Bank Indonesia, the Ministry of Trade of the Republic of Indonesia and the Mundi Index.

\section{Error Correction Model Estimation (ECM)}

The equation function model used in this study was:

$\mathrm{ER}=f(M 2, C A D E V, S B I, O P)$

From the equation of the function, the long run model used in this study was:

$E R_{t}=\alpha_{0}+\alpha_{1} M 2_{t}+\alpha_{2} C A D E V_{t}+\alpha_{3} S B I_{t}+\alpha_{4} O P_{t}+e_{t} \cdots$

While the short run model used was:

$$
\begin{aligned}
& \Delta E R_{t}=\alpha_{0}+\alpha_{1} \Delta M 2_{t}+\alpha_{2} \Delta C A D E V_{t}+\alpha_{3} \Delta S B I_{t}+\alpha_{4} \Delta O P_{t}+\alpha_{5} E C T+e_{t} \\
& \text { where: } \\
& \text { ER = Rupiah Exchange Rate Against United States Dollar } \\
& \text { M2 = Money Supply } \\
& \text { CADEV = Indonesian Foreign Exchange Reserves } \\
& \text { SBI }=\text { Bank Indonesia Certificate } \\
& \mathrm{OP} \quad=\text { Oil Price } \\
& \triangle \mathrm{ER} \quad=\text { Exchange Rate Changes } \\
& \triangle \mathrm{M} 2=\text { Money Supply Changes } \\
& \triangle \mathrm{CADEV}=\text { Indonesian Foreign Exchange Reserves Changes } \\
& \triangle \mathrm{SBI} \quad=\text { SBI Changes } \\
& \triangle \mathrm{OP} \quad=\text { Oil Price Changes } \\
& \text { ECT }=\text { Error Correction Term } \\
& \alpha_{0} \quad=\text { Constant } \\
& \alpha_{1}, \alpha_{2}, \alpha_{3}, \alpha_{4}=\text { Coefficient of ECM } \\
& \alpha_{5}=\text { Coefficient of ECT } \\
& e_{t} \quad=\text { Error Term } \\
& t \quad=\text { Time Period }
\end{aligned}
$$

\section{RESULT AND DISCUSSION \\ Data Stationarity Test}

Stationary is a time series data condition where the mean, variance, and covariance of the variables are not affected by time (Juanda, 2012). The stationary test method and the unit root that will be used in this research is the method of Augmented Dickey Fuller (ADF).

Table 1. Data Stationarity Test

\begin{tabular}{lllll}
\hline \multirow{3}{*}{ Variable } & \multicolumn{3}{c}{ Unit Root Test } \\
\cline { 2 - 5 } & \multicolumn{3}{c}{ Level } & \multicolumn{3}{c}{$1^{\text {st }}$ Difference } \\
\cline { 2 - 5 } & ADF & Prob & ADF & Prob \\
\hline
\end{tabular}


AFEBI Economic and Finance Review (AEFR)

Volume 5, No 02 (2020)

\begin{tabular}{lrrrr}
\hline $\begin{array}{l}\text { Exchange } \\
\text { Rate } \\
\text { M2 }\end{array}$ & -2.7447 & 0.0742 & - & 0.0000 \\
& 1.2025 & 0.9977 & 7.6443 & \\
$\begin{array}{l}\text { Foreign } \\
\text { Exchange }\end{array}$ & -1.6278 & 0.4607 & - & 0.0000 \\
$\begin{array}{l}\text { Reserves } \\
\text { SBI }\end{array}$ & & & -6.5020 & 0.0000 \\
Oil Price & -0.9889 & 0.7496 & - & 0.0045 \\
& -2.5259 & 0.1161 & 3.8707 & \\
& & & 5.3040 & 0.0001 \\
\hline
\end{tabular}

Source: E-views 10 Output, processed data

The processing results in the Table 1 , show that all variables are not stationary at the DF level, but have been stationary at the first difference level.

\section{Cointegration Test}

After knowing that the data was not stationary, the next step was to identify it to find out whether the data was cointegrated or not. For this reason, a cointegration test is needed. Cointegration test is used to give an initial indication whether the model used has a long-term relationship.

Cointegration test results are carried out by forming residuals obtained by regressing the independent variable to the dependent variable through OLS. The residual formed can be said to have cointegration, if it passes at the DF Level Stationary. The next step in this research that the residual was being tested for stationarity.

Table 2. Residual Stationarity Test

\begin{tabular}{cccrl}
\hline Variable & $\begin{array}{c}\text { ADF t- } \\
\text { statistic }\end{array}$ & $\begin{array}{c}\text { Critical Value } \\
5 \%\end{array}$ & Prob. & Result \\
\hline Residual & -3.8077 & -2.9251 & $\begin{array}{r}0.005 \\
4\end{array}$ & Stationary \\
\hline
\end{tabular}

Source: Output of E-views 10, processed data

From the table above, it is found that the residual is stationary at the level with a significant $t$ statistic value at the critical value of $5 \%$, with a probability value of 0.0054 . These results indicated that the data was cointegrated.

\section{Classic Assumption Test}

Normality Test

Table 3. Normality Test Result

\begin{tabular}{llll}
\hline & \multicolumn{2}{l}{ Histogram Normality Test } \\
\hline Jarque-Bera & 5.20630 & Probability & 0.074040 \\
& 5 & & \\
\hline
\end{tabular}


Source: Output of E-views 10, processed data

The result showed that the probability of 0.074040 is greater than $5 \%$ so that the data used is normally distributed.

\section{Multicollinearity}

Table 4 Multicollinearity Test Result

\begin{tabular}{lr}
\hline \multicolumn{1}{c}{ Variable } & Centered VIF \\
\hline C & NA \\
D1_M2 & 1.225934 \\
D1_Foreign & 1.317348 \\
Exchange Reserves & 1.042498 \\
D1_SBI & 1.055228 \\
D1_OP & 1.174097 \\
ECT(-1)
\end{tabular}

Source: Output of E-views 10, processed data

Based on the results of multicollinearity testing using the partial correlation method between independent variables, the results obtained that the model was free from multicollinearity symptoms. That was because all independent variables have a centered VIF value of less than 10 .

\section{Heteroscedasticity Test}

Table 5. Heteroscedasticity Test Result

\begin{tabular}{|c|c|c|c|}
\hline \multicolumn{4}{|c|}{ Heteroscedasticity Test: Breusch-Pagan-Godfrey } \\
\hline Obs* R-squared & $\begin{array}{l}3.58492 \\
0\end{array}$ & $\begin{array}{l}\text { Prob Chi- } \\
\text { squared }\end{array}$ & 0.6106 \\
\hline
\end{tabular}

Source: Output of Eviews10, processed data

Based on the results of the heteroscedasticity test, the results obtained that the prob Chi-Square value Obs*R-Squared of 0.6106 was greater than $5 \%$. So, it can be concluded that the model was free from heteroscedasticity problems.

\section{Autocorrelation Test}

Table 6. Autocorrelation Test Result

\begin{tabular}{lccc}
\hline \multicolumn{4}{c}{ Breusch-Godfrey Serial Correlation LM Test } \\
\hline $\begin{array}{c}\text { Obs* R- } \\
\text { squared }\end{array}$ & 0.905279 & Prob Chi-squared & 0.6359 \\
\hline
\end{tabular}

Source: Output of Eviews10, processed data 


\section{Volume 5, No 02 (2020)}

Based on the results of the autocorrelation test using Breusch-Godfrey Serial Correlation LM Test, the Prob value was obtained. Chi-Square of 0.6359 is greater than $5 \%$. It can be concluded that the ECM model was free from autocorrelation problems.

\section{Error Correction Model}

The Error Correction Model (ECM) test was conducted to determine the shortrun equation. The establishment of this ECM Model is intended to determine changes in the variables of inflation, foreign exchange reserves, SBI and world oil process against the rupiah exchange rate.

\section{Short-Run Estimation}

The short-run is a short-term equation made by changing the form of the dependent and independent variables into the first difference form.

Table 7. Short-Run Regression Result

\begin{tabular}{lrrc}
\hline \multicolumn{4}{c}{ Dependent Variables : Exchange Rate } \\
\hline \multicolumn{1}{c}{ Independent } & Coefficient & t-statistic & Prob. \\
\hline D1_M2 & 0.001853 & 3.909089 & 0.0003 \\
$\begin{array}{l}\text { D1_Foreign Exchange } \\
\text { Reserves }\end{array}$ & -0.098961 & 6.614621 & 0.0000 \\
& & - & \\
D1_SBI & -177.4282 & 0.826222 & 0.4135 \\
& -12.96510 & - & 0.0527 \\
D1_OP & & - & \\
ECT(-1) & -0.480257 & 3.517776 & 0.0011 \\
Constant & -20.14144 & 0.471763 & 0.6396 \\
\hline R-squared & & - & 0.733479 \\
F-statistic & & & 22.56681 \\
Prob. F-statistic & & & 0.000000 \\
\hline
\end{tabular}

Source: Output of Eviews10, processed data

Based on the table above, the estimation results of the short-run model using the Error Correction Model (ECM) method are as follows:

DExchangeRates $_{\mathrm{t}}=-20.14144+0.001853 \mathrm{DM}_{\mathrm{t}}-0.098961$ DForeignExchangeReserves $_{t}-177.4282 \mathrm{DSBI}_{t}-12.96510 \mathrm{OP}_{\mathrm{t}}-0.480257 \mathrm{ECT}(-1)$ $+e_{t}$ 
This study showed that ECT (-1) had a probability of 0.0011 which means that the probability value was less than 0.05 . In other words, the ECT variable showed significant results at the 5\% and was negative, which means that the ECM model was valid and there was an adjustment in the short-term model to achieve long-run equilibrium. In the short-run, the Money Supply variable or M2 had a positive and significant effect on the Rupiah Exchange Rate. So that changes in the Money Supply in the short-run of one billion rupiah will cause the Rupiah Exchange Rate to increase by 0.001853 . In the short-run, the variable of Foreign Exchange Reserves had a negative effect on the Rupiah Exchange Rate. So that the change in Foreign Exchange Reserves in the short-run of one million dollars will make the Rupiah Exchange Rate decrease by 0.098961 . In the short-run, the SBI variable had a negative and insignificant effect on the rupiah exchange rate. In the short-run, every $1 \%$ change will cause a decrease in the rupiah exchange rate of 177.4282 . In the short-run, the world oil price had a negative and insignificant effect on the Rupiah Exchange Rate. In the short-run, every 1 dollar change in world oil prices will cause a decrease in the rupiah exchange rate of 12.96510. The value of the coefficient of determination in the short-run estimation was 0.733479. This showed that the magnitude of the influence of the independent variables on the dependent variable was $73.35 \%$. While the remaining $26.65 \%$ was explained by variables outside the model.

\section{Long-Run Estimation}

Table 8. Long-Run Regression Result

\begin{tabular}{lrrc}
\hline \multicolumn{4}{c}{ Dependent Variable: Exchange Rate } \\
\hline Independent & Coefficient & t-statistic & Prob. \\
\hline M2 & 0.001242 & 10.90638 & 0.0000 \\
$\begin{array}{l}\text { Foreign Exchange } \\
\text { Reserves }\end{array}$ & -0.099418 & 7.023941 & 0.0000 \\
SBI & -153.9605 & 1.542590 & 0.1303 \\
& -4.775080 & 1.001537 & 0.3222 \\
OP & 20461.40 & 10.84553 & 0.0000 \\
Constant & & & 0.772328 \\
R-squared & & & 36.46714 \\
F-statistic & & & 0.000000 \\
Prob. F-statistic & & & \\
\hline
\end{tabular}

Source: Output of Eviews10, processed data

Table 8 shows the estimation result of the long run model in this study are as follows:

ExchangeRate $_{\mathrm{t}}=20461.40+0.001242 \mathrm{M} 2_{\mathrm{t}}-0.099418$ ForeignExchangeReserves $_{\mathrm{t}}$ $-153.9605 \mathrm{SBI}_{\mathrm{t}}-4.775080 \mathrm{OP}_{\mathrm{t}}+\mathrm{e}_{\mathrm{t}}$ 


\section{Volume 5, No 02 (2020)}

In the long run, the Money Supply variable or M2 had a positive and significant effect on the Rupiah Exchange Rate, so that a change in the Money Supply in the long run of one billion rupiah will cause the Rupiah Exchange Rate to increase by 0.001242 . In the long run, the Foreign Exchange Reserve variable had a negative and significant effect on the Rupiah Exchange Rate, thus a change in Foreign Exchange Reserves in the long run of one million dollars will make the Rupiah Exchange Rate to decrease by 0.099418. In the long run, the SBI variable had a negative and insignificant effect on the Rupiah Exchange Rate, so a 1\% change in the SBI in the long run will cause a decrease in the Rupiah Exchange Rate of 153.9605. In the long run, the variable World Oil Price or Oil Price had a negative and insignificant effect on the Rupiah Exchange Rate. Therefore, any change in World Oil Prices in the long run of 1 dollar will cause a decrease in the Rupiah Exchange Rate of 4.775080. The coefficient of determination value in the long run estimation was 0.772328 . This showed that the magnitude of the influence of the independent variable on the dependent variable was $77.23 \%$. while the remaining $22.77 \%$ was explained by variables outside the model.

\section{Discussion}

In the short and long run, the variable of Money Supply or M2 had a positive and significant effect on the Rupiah Exchange Rate in 2017-2020. This result is in line with the research of Demak et al., (2018) and Yuliyanti (2014) that in the short run and long run the Money Supply has a positive influence on the exchange rate. This condition is in accordance with the money supply theory which says that the money supply and the exchange rate have a positive relationship. When there is an increase in the domestic money supply, the domestic currency depreciates.

In the short run and long run, the variable of foreign exchange reserves had a negative and significant effect on the Rupiah Exchange Rate in 2017-2020. This result is in line with research of Yuliyanti (2014) which found that in the short run Foreign Exchange Reserves had a negative and significant effect on the value of the Exchange Rate. However, the long run results in this study are not in line with Yuliyanti (2014) which found that in the long run the Foreign Exchange Reserves have a positive and significant effect on the exchange rate. This condition is in accordance with the theory which states that there is a negative relationship between foreign exchange reserves and the exchange rate. The greater the amount of foreign exchange reserves, the foreign confidence in the country's ability to cope with external shocks also increases so that suppress speculation on the domestic currency which then makes the exchange rate strengthen.

In the short and long runs, the SBI variable had a negative and insignificant effect on the Rupiah Exchange Rate in 2017-2020. This result is in line with research of Yuliyanti (2014) which was stated that in the short run and long run the SBI interest rate had a negative effect on the change rate. This is also in accordance with the International Fisher Effect (IFE) theory which says that the exchange rate of a currency with another currency will change depending on the difference in interest rates between the two countries. In Keynesian Theory, a country's currency will appreciate if its interest rate is higher than that of other countries. Conversely, it will depreciate if the country's interest rate is lower than other countries. 
In the long and the short run, the World Oil Price variable had a negative and insignificant effect on the exchange rate. These results are in accordance with research conducted by Wijaya (2020) that world oil prices have a negative effect on exchange rates both in the short and long run. This is in accordance with the theory that an increase in world oil prices will lead to an increase in the price of domestic goods. This increase in the price of domestic goods will cause the real domestic exchange rate against the US dollar to depreciate.

\section{CONCLUSION}

Based on the results and discussion in this study, several conclusions can be drawn. First, in the short and long run, the money supply variable or M2 had a positive and significant effect on the Rupiah Exchange Rate in 2017-2020. Second, in the short run and long run, the variable of foreign exchange reserves had a positive and significant effect on the rupiah exchange rate in 2017-2020. Third, in the short and long run, the SBI variable had a negative and insignificant effect on the Rupiah Exchange Rate in 2017-2020. Fourth, in the short and long run, the variable World Oil Price or Oil Price had a negative and insignificant effect on the Rupiah Exchange Rate in 2017-2020.

Based on these conclusions, several things are recommended. First, the government must improve the balance of payments by suppressing Indonesia's imports so that the existing foreign exchange reserves do not decrease further for import payments so that the foreign exchange reserves can be saved and are expected to be able to support the rupiah exchange rate in the future. Second, the government must begin to reduce dependence on world crude oil and try to replace the use of fossil-based fuels with alternative fuels such as electricity, gas and other renewable energies. With the enactment of this policy, it is hoped that Indonesia will no longer have a high dependency on oil imports, so that Indonesia's foreign exchange reserves can be saved and the rupiah exchange rate will be better. Meanwhile, for further research, it is recommended to examine the effect of other macroeconomic variables that are not used in this research model. One of these limitations in this study is that the independent variables used have often been used by other researchers, and only the world oil price variable which is quite rarely used. Therefore, it is hope that the next research will use a combination of other independent variables so that the results of the next research are more diverse.

\section{References}

Artha, D. R., Achsani, N. A., \& Sasongko, H. (2014). Analisis Fundamental, Teknikal dan Makroekonomi Harga Saham Sektor Pertanian. Jurnal Manajemen Dan Kewirausahaan (JMK), 16(2), 175-184.

BI. (2021a). BI 7-Day Repo Rate.

BI. (2021b). Cadangan Devisa.

Demak, U. D. L. K., Kumaat, R. J., \& Mandeij, D. (2018). Pengaruh Suku Bunga Deposito, Jumlah Uang Beredar, dan Inflasi terhadap Nilai Tukar Rupiah terhadap Dollar. Jurnal Berkala Ilmiah Efisiensi, 18(2), 181-192. 


\section{AFEBI Economic and Finance Review (AEFR)}

\section{Volume 5, No 02 (2020)}

Emmanuel, U. C. (2013). Accumulation of external reserves and effects on exchange rates and inflation in Nigeria. International Business and Management, 6(2), 105114.

Hady, H. (2006). Manajemen Keuangan Internasional. Mitra Wacana Media.

Hazizah, N., Viphindrartin, S., \& Zainuri, Z. (2017). Pengaruh JUB, Suku Bunga, Inflasi, Ekspor dan Impor terhadap Nilai Tukar Rupiah atas Dolar Amerika Serikat. E-Journal Ekonomi Bisnis Dan Akuntansi, 4(1), 97-103.

Indexmundi. (2021). Crude Oil (Petroleum).

Juanda, B. J. (2012). Ekonometrika Deret Waktu: Teori dan Aplikasi. IPB Press.

Kemendag. (2021a). Exchange Rates.

Kemendag. (2021b). Jumlah Uang Beredar.

Mirchandani, A. (2013). Analysis of macroeconomic determinants of exchange rate volatility in India. International Journal of Economics and Financial Issues, 3(1), 172-179.

Mishkin, F. S. (2014). Ekonomi, Uang, Perbankan dan Pasar Keuangan (9th ed.). Salemba Empat.

Muchlas, Z., \& Agus, R. A. (2015). Faktor-Faktor Yang Mempengaruhi Kurs Rupiah Terhadap Dolar Amerika Pasca Krisis (2000-2010). Jurnal Jibeka, 9(1), 78-86.

Mulyani, P. A. (2015). Kajian Terhadap Faktor - Faktor yang mempengaruhi Subsidi Bahan Bakar Minyak (BBM) Indonesia. Jurnal Ekonomi Kuantitatif Terapan, 8(1).

Muzaky. (2015). Pengaruh Inflasi, Tingkat Suku Bunga, SBI, Pendapatan Perkapita, Dan Ekspor Terhadap Nilai Tukar Rupiah Dan Pertumbuhan Ekonomi. Jurnal Administrasi Bisnis, 23(1).

Pardede, A.S.M. \& Setiawina, N. D. (2018). Pengaruh Indeks Harga Saham Gabungan, Suku Bunga dan Harga Minyak Dunia terhadap Nilai Tukar Rupiah Tahun 2012 2016. E-Jurnal Ekonomi Pembangunan Universitas Udayana, 7(8), 1708-1736.

Triyono. (2008). Analisis Perubahan Kurs Rupiah Terhadap Dollar Amerika. Jurnal Ekonomi Pembangunan, 9(2), 156-167. 
Wijaya, E. (2020). Analisis Faktor-Faktor yang Mempengaruhi Nilai Tukar Rupiah Periode 1999Q1-2019Q2. Jurnal Samudra Ekonomi Dan Bisnis, 11(2).

Yuliyanti, I. N. (2014). Pengaruh Jumlah Uang Beredar (M2), Tingkat Suku Bunga Sbi, Impor, Dan Cadangan Devisa Terhadap Nilai Tukar Rupiah / Dolar Amerika Tahun 2001 - 2013. Economics Development Analysis Journal, 3(2), 284-292. https://doi.org/https://doi.org/10.15294/edaj.v3i2.3834 